\title{
Occupational and other environmental factors and multiple myeloma: a population based case-control study
}

\author{
Mikael Eriksson, Maria Karlsson
}

\begin{abstract}
Epidemiological studies on the aetiology of multiple myeloma are reviewed as a background to this population based case-control study performed in an area with a high incidence of multiple myeloma. The purpose was to identify and evaluate several suspected environmental factors in relation to this disease. A total of 275 confirmed cases diagnosed in four counties in northern Sweden during four years were compared with the same number of control subjects drawn from population registries. The controls were matched for age, sex, county, and vital status. Occupations and work associated exposures to chemicals and other potential carcinogens were assessed by an extensive questionnaire that also included questions on smoking habits, residential building materials, vicinity to electrical power lines, and leisure time contact with animals, electrical equipment, and chemicals. Information obtained from the questionnaires was completed by telephone interviews when necessary. Univariate analysis and multivariate logistic regression were performed. The study confirmed an association found earlier between farming and multiple myeloma. Some domestic animals (cattle, horses, and goats) and two types of pesticides (phenoxyacetic acids and DDT) were indicated as risk factors within farming. Exposure to electromagnetic fields, asbestos, and organic solvents were negatively associated with myeloma in this study.
\end{abstract}

Multiple myeloma is an incurable malignant lymphoproliferative disease with an increasing incidence and mortality in several countries. The causes of the

Department of Oncology, University Hospital, S-901 85 Umeâ, Sweden

M Eriksson

Department of Occupational Medicine, University Hospital, S-581 85 Linköping, Sweden

M Karlsson disease are poorly understood. Some reports on familial multiple myeloma indicate a possible hereditary influence. ${ }^{1-4}$

Exposure to high doses of ionising radiation is now generally accepted as a factor increasing the risk of developing multiple myeloma. Atomic bomb survivors in Hiroshima and Nagasaki have been clearly shown to have a dose related increase in the risk for multiple myeloma, with rather long latency periods..$^{5-7}$ Workers at the Hanford atomic plant in Washington State have been followed up regarding different causes of death, and a statistically significant dose-response trend for degree of radiation exposure has been obtained for multiple myeloma, although this was based on few exposed cases. ${ }^{8-11}$ A survey of all cohorts of persons exposed to radiation for which data on cancer related mortality were available showed an excess of multiple myeloma in most cohorts. ${ }^{12}$

An association between farming and multiple myeloma was first found in a case-control study from Washington State. ${ }^{13}$ Several studies with different methodologies and from different countries have confirmed this finding, ${ }^{14-26}$ but some other recent epidemiological studies do not support the association. ${ }^{27} 28$ In a case-control study from the middle of Sweden a statistically significant increased crude rate ratio (RR) of 1.9 for farming was obtained, but in further analysis with multiple regression the $R R$ decreased to $1 \cdot 4$, which was not significant. ${ }^{29}$

Some studies have investigated further the possible connection between farming and multiple myeloma by trying to identify specific risk factors. Thus some American studies with different methodologies indicate an association between exposure to pesticides and multiple myeloma ${ }^{1623} 3031$ but no firm conclusions could be drawn concerning any particular class of pesticides responsible for the increase in risk. A study from New Zealand did not find any significant differences between cases and controls regarding potential exposure to phenoxy herbicides, chlorophenols, or any other agricultural chemicals, whereas significantly raised RRs were found for sheep farming and exposure to beef cattle. ${ }^{19}$

Exposure to asbestos has been connected with 
multiple myeloma in two recent case-control studies, ${ }^{21}{ }^{27}$ but by contrast a recent American study did not find any such association. ${ }^{23}$ Furthermore, an American multicentre population based case-control study did not find any correlation between jobs with probable exposure to asbestos and multiple myeloma. ${ }^{32}$

Benzene is an established risk factor for acute leukaemia, and multiple myeloma and other haematological malignancies have been associated with exposure to benzene or other organic solvents. 2313334 Occupational exposure to petroleum products gave an increased risk for myeloma in a case-control study ${ }^{27}$ as well as in a cohort study, ${ }^{35}$ both from the United States. Other chemical exposures associated with observed increases in incidence or mortality in multiple myeloma in single studies encompass arsenic, ${ }^{36}{ }^{37}$ lead ${ }^{38}$ carbon monoxide, ${ }^{31}$ and engine exhausts and creosote. ${ }^{29}$ Some specific occupations with potential exposure for different chemicals have also been identified as entailing an increased risk of myeloma-for example, hairdressers and cosmetologists, ${ }^{14} 3940$ machinists, ${ }^{41}$ and leather workers. ${ }^{4243}$

Some studies have connected multiple myeloma with the furniture industry ${ }^{44} 45$ or carpentry. ${ }^{14}$ Furthermore, a Swedish case-control study found woodworkers in contact with fresh wood to be at risk for myeloma. ${ }^{29}$

The possible carcinogenic effect of electromagnetic fields has been much debated in recent years as a result of some epidemiological studies. A cohort study from the western United States investigating mortality in amateur radio operators exposed to electromagnetic fields showed a statistically significant increased mortality from malignancies of lymphatic tissues, including multiple myeloma and non-Hodgkin's lymphoma. ${ }^{46}$

The present study investigated those suspected risk factors for multiple myeloma, in a high incidence area of Sweden. Special emphasis was placed upon possible hazards in farming, such as contact with pesticides and different domestic animals.

\section{Materials and methods \\ CASES}

All persons living in the four most northern counties of Sweden who were diagnosed as having multiple myeloma and were reported to the Swedish Cancer Registry between 1 July 1982 and 30 June 1986 were eligible for inclusion in this study. In Sweden all physicians are obliged to report all incident cases of malignant tumours to the Cancer Registry.

In this way 293 patients with a diagnosis of myeloma were identified. The medical records of these patients were scrutinised to confirm the diagnosis, and all cases who could not fulfil widely accepted diagnostic criteria proposed for use in therapeutic trials ${ }^{4 T}$ were excluded. A total of 18 patients did not meet these criteria. The remaining 275 patients constituted the cases; $156(57 \%)$ of these were alive and $119(43 \%)$ were deceased. No restrictions regarding age or sex were used. Of all cases 141 were men and 134 were women.

\section{CONTROLS}

For every living case two eligible control persons were extracted from the Swedish National Population Registry. This was done through a matching procedure taking into consideration age, sex, and county. In Sweden everybody has a unique personal identity number composed of date of birth and four additional figures. The two persons with same sex, living in the same county and being closest in personal identity number-that is, in age-to the respective case were selected, and from these two, one was randomly chosen as the control person.

For each deceased case, one deceased control was selected in an equivalent way from the National Registry for Causes of Death. The same matching criteria as for the living cases were used, and, furthermore, the deceased controls were matched on year of death. For reasons of humanity, persons who committed suicide were not used as controls. The study thus involved 275 cases and 275 controls, in all 550 persons.

\section{ASSESSMENT OF EXPOSURE}

An extensive questionnaire was mailed to all living subjects in the study. To obtain data concerning deceased persons the questionnaire was sent to the next of kin defined in the order of husband or wife, child, parent, sibling, or other. The specific nature of the investigation was not disclosed, and there was no reference to the special disease under study. Instead, the general information given was that different factors of potential importance for health were studied. The questionnaires contained several questions regarding the persons' various jobs over the years, as well as time and place for employment, and work associated exposure to chemicals and other potential carcinogens. It also included questions about smoking habits, residential building materials, vicinity to electrical power lines, and leisure time contact with animals, electrical equipment, and chemicals.

At the end of the questionnaire were some pages with questions concerning diseases, medications, and other treatments, as well as an inquiry about hereditary circumstances. These pages were detached and filed by a secretary for later analysis when the questionnaires were returned from the subjects, so as not to disclose whether the subject was a case or a control. That particular information is not considered further in this presentation.

After this all questionnaires were handed over to a 
specially trained interviewer who did not know whether the persons were cases or controls. The interviewer scrutinised all answers and supplemented them by telephone according to written instructions if any data were unclear or incomplete. Some subjects, or next of kin, were unable or unwilling to answer the questionnaire, but accepted a telephone interview, which did not then include the questions about diseases, treatments, and heredity. This avoided interviewer bias by not disclosing whether the subject was a case or control.

All persons who had been working in agriculture were carefully questioned if any answers about livestock or use of pesticides were missing. Furthermore, regardless of the answers in that respect all persons who had been working within farming, forestry, or horticulture during the period when pesticides have been used in Sweden (since 1945) were phoned to ensure a good and uniform assessment of exposure to such chemicals. In the same way all persons who, during this period, had been employed in saw mills, where different biocides have been used to protect against blue stain and as impregnates, or employed as roadworkers, or railroad embankment workers were phoned to verify and specify any exposure to pesticides.

After the questionnaires had been completed by the interviewer, the front page, including name, personal identification number, and address, was removed, thus enabling a blinded coding of the answers by one of us (ME).

Some special considerations were taken into account when assessing different exposures. Thus as in earlier epidemiological studies in the same geographical area a minimum exposure of one whole working day was used for exposure to phenoxyacetic herbicides and the related chlorophenols.

If the information about type or trade names of biocides was lacking or unsure, even if there was a strong suspicion, the subject was only regarded as exposed to pesticides in general and not to any specific type of substance.

Exposure to organic solvents is common in some occupations, and also occurs in some leisure time work and hobby activities. Separate analyses were done for these two types of exposure.

Enquiries about the building material of all dwellings inhabited by the subjects were made. In the analysis, the subjects were regarded as exposed if they had ever lived in a house built of the material in question. Wood, stone, concrete, light concrete, plaster and brick were thereby analysed separately. According to estimations of $\gamma$-radiation from different building materials in Swedish dwellings ${ }^{48}$ stone, concrete, and light concrete houses were also analysed by aggregation, and the same was done for plaster and brick houses.

Only subjects who reported that they had been living less than $1 \mathrm{~km}$ from electric power lines were regarded as exposed to an electromagnetic field.

The above mentioned criteria for different exposures were all decided before the coding of exposure.

\section{STATISTICAL METHODS}

For calculation of the $\mathbf{R}$ the maximum likelihood estimate was used, both in univariate and multivariate models. The procedures "match" and "logreg" in the statistical computer program "Epilog" was used for the univariate matched analysis and the multivariate logistic regression respectively. The $90 \%$ confidence intervals ( $90 \% \mathrm{CIs}$ ) were obtained with the approximative procedure described by Miettinen ${ }^{49}$ in the "match" procedure, and with the Newton-Raphson interactive technique in the "logreg". In all analyses the matched pairs were kept together.

All occupations as well as specific exposures were analysed in univariate analyses. Multivariate logistic regression was then used to evaluate the importance of different exposure factors. Occupations were not included in the multivariate model, as these were strongly connected with the specific exposure variables-for example, farmers with domestic animals. The following criteria were used to choose the exposure variables to be included in the multivariate model:

The $\mathbf{R R}$ in the univariate analysis had to be either (a) statistically significant with a $90 \%$ CI not including unity, or $(b) \geqslant 1.5$ or $\leqslant 0.67(1 / 1.5)$, and representing at least 10 exposed subjects.

The variables should not cover other specific exposure variables. Thus the variable "all pesticides", which covers different specific pesticides, as well as the variables with combined types of building materials mentioned above, were excluded.

All variables that could meet these criteria were thus analysed in a multivariate model, in which all factors with a risk estimate between 0.9 and 1.1 were gradually excluded. Also, to check any potential confounding from variables not primarily included in the model, the Pearson-correlation coefficient among the referents was used. ${ }^{50}$ Thus factors with an absolute value of the correlation coefficient $\geqslant 0 \cdot 25$ and with at least 10 subjects exposed were considered as relevant, and they were included in the model after the initial exclusion steps (table 5).

\section{Results}

Of the 312 living subjects, 12 refused to participate in the study, and of the 238 deceased, no answers were obtained from the relatives of seven persons. The refusal rate was consequently $3.45 \%$. Six of the refusers were cases and 13 were controls. Thus 19 subjects and their 19 matched counterparts could not 
Table 1 Occupations and exposures with a statistically significant increased or decreased $R R$ in univariate analysis

\begin{tabular}{|c|c|c|c|}
\hline $\begin{array}{l}\text { Occupation/ } \\
\text { exposure factor }\end{array}$ & $\begin{array}{l}\text { No of } \\
\text { exposed } \\
\text { cases }\end{array}$ & $\begin{array}{l}\text { No of } \\
\text { exposed } \\
\text { controls }\end{array}$ & $R R(90 \% C I)$ \\
\hline \multicolumn{4}{|l|}{ Occupation: } \\
\hline $\begin{array}{l}\text { Farmer } \\
\text { Electrician }\end{array}$ & $\begin{array}{r}151 \\
3\end{array}$ & $\begin{array}{r}121 \\
9\end{array}$ & $\begin{array}{l}1.68(1.23-2.33) \\
0.33(0.11-0.81)\end{array}$ \\
\hline \multicolumn{4}{|l|}{ Exposure factor: } \\
\hline $\begin{array}{l}\text { Power saw } \\
\text { Asbestos } \\
\text { Organic solvents }\end{array}$ & $\begin{array}{l}40 \\
19\end{array}$ & $\begin{array}{l}27 \\
33\end{array}$ & $\begin{array}{l}1.57(1.01-2.48) \\
0.50(0.29-0.82)\end{array}$ \\
\hline (occupational) & 21 & 37 & $0.50(0.30-0.80)$ \\
\hline Pesticides, all & 81 & 59 & $1 \cdot 55(1 \cdot 15-2 \cdot 26)$ \\
\hline Phenoxy acids & 20 & 9 & $2 \cdot 22(1 \cdot 15-4 \cdot 66)$ \\
\hline DDT & 53 & 32 & $1.75(1 \cdot 19-2 \cdot 64)$ \\
\hline Copy machines & 6 & 14 & $0.43(0.19-0.87)$ \\
\hline \multicolumn{4}{|l|}{ Electromagnetic fields } \\
\hline (occupational) & 6 & 15 & $0.31(0.12-0.66)$ \\
\hline Cattle & 152 & 118 & $1.72(1 \cdot 27-2 \cdot 36)$ \\
\hline Horses & 137 & 101 & $1.78(1 \cdot 32-2 \cdot 45)$ \\
\hline Hogs & 124 & 99 & $1.49(1 \cdot 11-2 \cdot 03)$ \\
\hline Sheep & 60 & 41 & $1.66(1 \cdot 12-2 \cdot 49)$ \\
\hline Goats & 24 & 11 & $2 \cdot 18(1 \cdot 20-4 \cdot 24)$ \\
\hline
\end{tabular}

be used in the analysis, which deals with the remaining 512 subjects or 256 matched pairs.

\section{UNIVARIATE ANALYSIS}

Table 1 shows the result of the univariate analysis for occupations and exposures with a statistically significant increased or decreased risk. In tables 2 and 3 other occupations and exposure factors with at least 10 exposed subjects or of a special interest because of

Table 2 Occupations without any statistically significant differences between cases and controls in univariate analysis. Only variables with at least 10 exposed subjects or of special interest due to findings in earlier studies are included

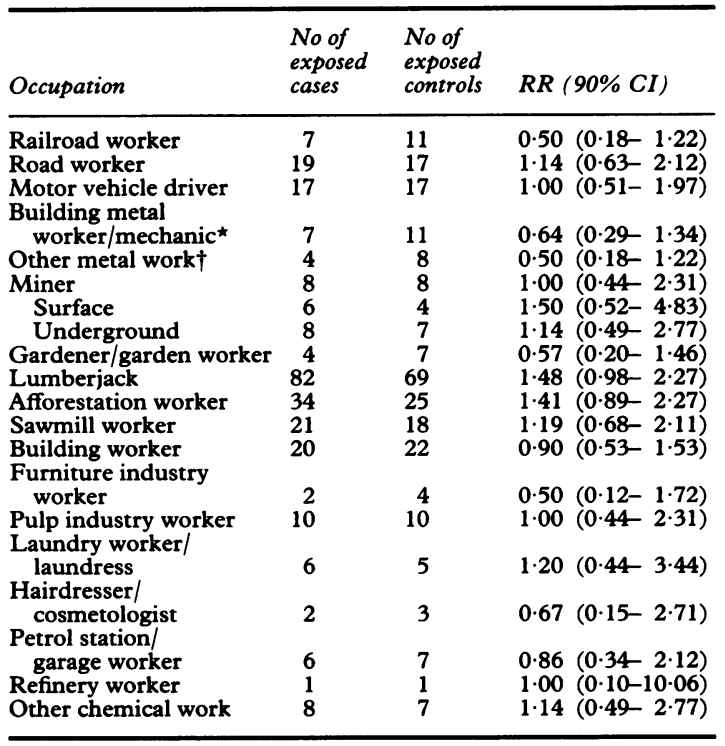

* Machine-repairman, welder, and plumber included.

†Blacksmith, turner, and founder included. results in earlier studies on multiple myeloma are presented.

Among occupations only farmers showed an increased risk for myeloma, whereas electricians seemed to be negatively associated with the disease.

Exposure to any pesticides resulted in a significantly increased risk, which was further augmented when only phenoxyacetic herbicides were considered. Exposure to dichlorodiphenyltrichloroethane (DDT) also gave an increased risk for myeloma. On the other hand, no increased risks were noted for exposure to chlorophenols, creosote, arsenic, or mercurial seed dressing. Each and every other type of pesticide was just mentioned sporadically, and none gave a significant $R R$.

Increased risks were also noted for exposure to different domestic animals-namely, cattle, horses, hogs, sheep, and goats-but not for poultry or any other animals.

Exposure to asbestos gave, contrary to the results of some other studies, a decreased risk for myeloma. Occupational exposure to organic solvents also

Table 3 Exposure factors without any statistically significant differences between cases and controls in univariate analysis. Only variables with at least 10 exposed subjects or of a special interest due to findings in earlier studies are included

\begin{tabular}{|c|c|c|c|}
\hline Exposure factor & $\begin{array}{l}\text { No of } \\
\text { exposed } \\
\text { cases }\end{array}$ & $\begin{array}{l}\text { No of } \\
\text { exposed } \\
\text { controls }\end{array}$ & $R R(90 \% C I)$ \\
\hline Welding & 3 & 7 & $0.43(0.14-1 \cdot 12)$ \\
\hline Tractor driving & 19 & 15 & $1.40(0.71-2.89)$ \\
\hline Sulphite pulp & 6 & 8 & $0.67(0.23-1.81)$ \\
\hline Chlorophenols & 20 & 19 & $1.06(0.60-1.90)$ \\
\hline Organic solvents & & 37 & $(0.80-1.89)$ \\
\hline $\begin{array}{l}\text { (leisure time use) } \\
\text { Man made mineral }\end{array}$ & 43 & 31 & $1.22(0.00-1.09)$ \\
\hline fibres & 14 & 13 & $1.08(0.56-2 \cdot 13)$ \\
\hline Arsenic & 4 & 3 & $1.33(0.38-5.21)$ \\
\hline Creosote & 4 & 5 & $0.75(0.21-2.51)$ \\
\hline Mercurial seed dressing & 5 & 3 & $1.67(0.50-6.44)$ \\
\hline Electromagnetic fields: & & & \\
\hline Leisure time exposure & 6 & 5 & $1.20(0.44-3.44)$ \\
\hline Amateur radio operator & 2 & 2 & $1.00(0 \cdot 19-5 \cdot 37)$ \\
\hline Power line near home & 40 & 42 & $0.94(0.64-1.40)$ \\
\hline Display monitor unit & 3 & 5 & $0.60(0.18-1.80)$ \\
\hline Poultry & 86 & 74 & $1.24(0.91-1.71)$ \\
\hline Dogs & 137 & 140 & $0.96(0.72-1.27)$ \\
\hline Cats & 112 & 106 & $1.11(0.82-1.51)$ \\
\hline Birds & 9 & 15 & $0.50(0.22-1.05)$ \\
\hline \multicolumn{4}{|l|}{ Building material (home): } \\
\hline Wood & 249 & 248 & $1 \cdot 14(0.49-2 \cdot 77)$ \\
\hline Light concrete & 20 & 17 & $1.20(0 \cdot 68-2 \cdot 17)$ \\
\hline Concrete & 48 & 60 & $0.76(0.53-1.07)$ \\
\hline Brick & 45 & 56 & $0.77(0.53-1.09)$ \\
\hline Plaster & 12 & 14 & $0.86(0.45-1.63)$ \\
\hline Stone & 17 & 19 & $0.89(0.52-1.54)$ \\
\hline \multicolumn{4}{|l|}{ Light concrete, } \\
\hline $\begin{array}{l}\text { concrete, stone } \\
\text { Plaster, brick }\end{array}$ & $\begin{array}{l}72 \\
51\end{array}$ & $\begin{array}{l}88 \\
63\end{array}$ & $\begin{array}{l}0.74(0.55-1.01) \\
0.77(0.55-1.08)\end{array}$ \\
\hline \multicolumn{4}{|l|}{ Radioactivity in } \\
\hline work & 2 & 3 & $0.67(0.15-2 \cdot 71)$ \\
\hline Smoking & 106 & 117 & $0.80(0.57-1.11)$ \\
\hline Fresh wood * & 92 & 81 & $1.48(0.95-2.35)$ \\
\hline Engine exhausts $\dagger$ & 61 & 50 & $1.38(0.92-2.09)$ \\
\hline
\end{tabular}

^Working with power saws, at a sawmill, or at a pulp industry. + Working with tractor, power saws, or as drivers. 
Table 4 Dose-response calculation on exposure factors with reliable information about duration of exposure and statistically significant deviated risks in univariate analysis as presented in table 1. The categories of exposure (decided before analysis was done) refer to days of work with phenoxyacetic acids and DDT and years of exposure for the rest of the factors

\begin{tabular}{|c|c|c|c|c|}
\hline \multirow[b]{3}{*}{$\begin{array}{l}\text { Exposure factor } \\
\text { Phenoxyacetic acids } \\
\text { Organic solvents (work) } \\
\text { Asbestos } \\
\text { DDT } \\
\text { Cattle } \\
\text { Horses } \\
\text { Hogs } \\
\text { Sheep } \\
\text { Goats }\end{array}$} & \multicolumn{4}{|l|}{ Duration of exposure } \\
\hline & $\leqslant 5(R R(90 \% C I))$ & 6-20(RR (90\% CI )) & \multicolumn{2}{|c|}{$\geqslant 21(R R(90 \% C I))$} \\
\hline & $\begin{array}{ll}3.00 & (0.78-11.49) \\
0.37 & (0.09-1.48) \\
0.10 & (0.02-0.66) \\
1.08 & (0.41-2.81) \\
1.69 & (0.68-4.20) \\
1.87 & (0.63-5.53) \\
2.10 & (0.65-6.75) \\
1.39 & (0.55-3.54) \\
- & \end{array}$ & $\begin{array}{ll}2.00 & (0.63-6.40) \\
0.59 & (0.28-1.25) \\
0.21 & (0.06-0.66) \\
1.54 & (0.86-2.77) \\
1.30 & (0.83-2.05) \\
1.17 & (0.73-1.86) \\
0.97 & (0.60-1.54) \\
1.22 & (0.63-2.38) \\
1.00 & (0.34-2.59)\end{array}$ & $\begin{array}{l}2 \cdot 00 \\
0 \cdot 37 \\
0.58 \\
1.61 \\
1.85 \\
1.86 \\
1.56 \\
2 \cdot 13 \\
3.20\end{array}$ & $\begin{array}{l}(0 \cdot 73-5 \cdot 48) \\
(0 \cdot 18-0 \cdot 74) \\
(0 \cdot 26-1 \cdot 31) \\
(0 \cdot 63-4 \cdot 12) \\
(1 \cdot 33-2 \cdot 57) \\
(1 \cdot 33-2 \cdot 59) \\
(1 \cdot 12-2 \cdot 19) \\
(1 \cdot 30-3 \cdot 94) \\
(1 \cdot 38-7 \cdot 43)\end{array}$ \\
\hline
\end{tabular}

seemed to be negatively associated with myeloma, but leisure-time use gave a slightly increased risk.

Exposure to electromagnetic fields during work, which is the case for electricians and for linemen, and some other occupations, also gave a decreased RR, whereas residential exposure from power lines produced a risk around unity.

No statistically significant increased risk resulted from any type of residential building material, or from occupational exposure to radioactivity, activity as an amateur radio operator, work as hairdresser, or cosmetologist, or smoking.

For some exposure factors such as chemicals, animals, and residential building materials, where information on duration of exposure was good, a dose-response analysis was performed. Table 4 presents the results of this calculation for exposure factors with a statistically significant increased or decreased risk in the univariate analysis (table 1).

Exposures to several domestic animals showed statistically significant increased $R R$ only at the highest dose. This indicates a dose-response pattern and further supports an association between these animals and multiple myeloma.

\section{MULTIVARIATE ANALYSIS}

In the multivariate analysis several exposure factors were included according to the criteria described. Table 5 presents the stepwise reduction with the resulting values of $R R s$. The $90 \%$ CIs of the RRs in the last step are also given.

Exposure to hogs and sheep were eliminated as risk

Table 5 Multivariate analysis of different exposure factors chosen according to the criteria described in STATISTICAL METHODS. Univariate risk ratios (URRs) are given, and a stepwise reduction with resulting values of risk ratios is presented as well as $90 \%$ CIs of the values in the reduced model. All variables with a risk estimate between 0.9 and $1 \cdot 1$ were gradually excluded. The Pearson-correlation coefficient was used to include potential confounding factors not primarily included in the model (see text)

\begin{tabular}{|c|c|c|c|c|c|c|}
\hline \multirow[b]{2}{*}{ Exposure factor } & \multirow[b]{2}{*}{ URR } & \multicolumn{4}{|c|}{ Step No } & \multirow[b]{2}{*}{$(90 \% C I)$} \\
\hline & & 1 & 2 & 3 & 4 & \\
\hline $\begin{array}{l}\text { Cattle } \\
\text { Horses } \\
\text { Hogs } \\
\text { Sheep }\end{array}$ & $\begin{array}{l}1.72 \\
1.78 \\
1.49 \\
1.66\end{array}$ & $\begin{array}{l}1.52 \\
1.45 \\
0.71 \\
0.95\end{array}$ & $\begin{array}{l}1.51 \\
1.45 \\
0.70\end{array}$ & $\begin{array}{l}1.54 \\
1.66 \\
0.84\end{array}$ & $\begin{array}{l}1.48 \\
1.64 \\
0.85\end{array}$ & $\begin{array}{l}(0.76-2.91) \\
(0.93-2.91) \\
(0.42-1.69)\end{array}$ \\
\hline $\begin{array}{l}\text { Goats } \\
\text { Poultry }\end{array}$ & $\begin{array}{l}2 \cdot 18 \\
1 \cdot 24\end{array}$ & 1.37 & 1.33 & $\begin{array}{l}1.50 \\
0.68\end{array}$ & $\begin{array}{l}1.51 \\
0.68\end{array}$ & $\begin{array}{l}(0 \cdot 75-3 \cdot 03) \\
(0.40-1 \cdot 15)\end{array}$ \\
\hline $\begin{array}{l}\text { Cats } \\
\text { Dogs }\end{array}$ & $\begin{array}{l}1 \cdot 11 \\
0.96\end{array}$ & & & $\begin{array}{l}0.91 \\
0.80\end{array}$ & 0.79 & $(0.56-1 \cdot 10)$ \\
\hline Birds & 0.50 & 0.73 & 0.73 & 0.69 & 0.69 & $(0 \cdot 27-1 \cdot 77)$ \\
\hline $\begin{array}{l}\text { Phenoxyacetic acids } \\
\text { Chlorophenols }\end{array}$ & $\begin{array}{l}2.22 \\
1.06\end{array}$ & 1.60 & 1.60 & $\begin{array}{l}1.87 \\
0.86\end{array}$ & $\begin{array}{l}1.92 \\
0.85\end{array}$ & $\begin{array}{l}(0.84-4 \cdot 36) \\
(0 \cdot 40-1 \cdot 80)\end{array}$ \\
\hline DDT & 1.75 & 1.29 & 1.29 & 1.42 & 1.40 & $(0 \cdot 88-2 \cdot 25)$ \\
\hline Organic solvents (work) & 0.50 & 0.61 & 0.61 & 0.68 & $0 \cdot 67$ & $(0 \cdot 38-1 \cdot 21)$ \\
\hline Asbestos & $0 \cdot 50$ & 0.66 & $0 \cdot 67$ & 0.52 & 0.54 & $(0 \cdot 27-1 \cdot 08)$ \\
\hline Sulphite pulp & 0.67 & 0.87 & 0.88 & 0.91 & & \\
\hline Power saw & 1.57 & 0.88 & $0 \cdot 87$ & 0.78 & 0.75 & $(0 \cdot 36-1 \cdot 58)$ \\
\hline Copy machine & 0.43 & 0.55 & 0.54 & 0.59 & 0.55 & $(0 \cdot 23-1 \cdot 33)$ \\
\hline Electromagnetic fields (work) & $0 \cdot 31$ & 0.32 & 0.32 & $0 \cdot 37$ & 0.36 & $(0.13-0.99)$ \\
\hline Fresh wood $\star$ & 1.48 & & & 0.90 & & \\
\hline Engine exhausts ${ }^{\star}$ & 1.38 & & & $1 \cdot 11$ & $1 \cdot 11$ & $(0.60-2.05)$ \\
\hline Man made mineral fibres & 1.08 & & & 2.00 & $2 \cdot 00$ & $(0 \cdot 83-4 \cdot 82)$ \\
\hline Brick $\dagger$ & 0.77 & & & 0.91 & & \\
\hline
\end{tabular}

$\star$ Defined as in table 3 .

+Building material in dwelling. 
Table 6 Some exposure factors within farming and forestry. Only matched pairs with both subjects being occupied in those industries $(n=94)$ were included in the analysis

\begin{tabular}{lll}
\hline Exposure factor & \multicolumn{2}{l}{$R R(90 \% \mathrm{CI})$} \\
\hline Cattle & $2 \cdot 00$ & $(0 \cdot 93-4 \cdot 70)$ \\
Horses & $1 \cdot 64$ & $(0 \cdot 94-2 \cdot 99)$ \\
Hogs & $1 \cdot 00$ & $(0 \cdot 59-1 \cdot 71)$ \\
Sheep & $1 \cdot 26$ & $(0 \cdot 76-2 \cdot 13)$ \\
Goats & $1 \cdot 71$ & $(0 \cdot 78-4 \cdot 06)$ \\
Poultry & $1 \cdot 04$ & $(0 \cdot 65-1 \cdot 68)$ \\
Phenoxyacetic acids & $2 \cdot 00$ & $(0 \cdot 88-5 \cdot 07)$ \\
Chlorophenols & $1 \cdot 14$ & $(0 \cdot 49-2 \cdot 77)$ \\
DDT & $1 \cdot 86$ & $(1 \cdot 08-3 \cdot 35)$ \\
Mercurial seed dressing & $1 \cdot 00$ & $(0 \cdot 19-5 \cdot 37)$ \\
Pesticides, other & $0 \cdot 71$ & $(0 \cdot 27-1 \cdot 79)$ \\
Tractor driving (farming) & $2 \cdot 25$ & $(0 \cdot 84-7 \cdot 11)$ \\
\hline
\end{tabular}

factors for myeloma in the multivariate setting, whereas exposure to cattle, horses, and goats seemed to remain important although RRs were weakened. Phenoxyacetic herbicides and DDT also remained as risk factors, but with slightly decreased RRs.

The significantly decreased risk connected with exposure to electromagnetic fields during work remained. Exposure to organic solvents and asbestos was still negatively associated with myeloma but with less pronounced decreased RRs.

Some exposure variables were introduced in the model as they were fulfilling the correlation criterion described above, but of these only man made mineral fibres gave an increased risk.

For further details on this multivariate analysis see table 5 .

In another approach to study the importance of different specific factors within farming and related work, a separate analysis was done including only the pairs with both subjects affirming work in farming or forestry. A total of 94 pairs were used in this analysis. It confirmed the mentioned domestic animals and pesticides as possible risk factors for multiple myeloma (table 6).

\section{Discussion}

This study was performed to further evaluate risk factors for multiple myeloma described in other studies. The Swedish compulsory reporting system for malignant diseases makes it likely that almost all incident cases in the study area during the four years of inclusion were utilised. A matched study design controlling for age, sex, county, and vital status was used, thereby increasing efficacy in the analysis.

To reduce the possible influence of recall bias-for example, a supposed tendency for the cases to remember more hazardous exposures than controls - the aim of the study was unexpressed. Thus no allusion to the disease under study was made in the information to the subjects. Furthermore, the questionnaire asked for information on many different occupations and exposures not specially focussing on any debated risk factors.

To minimise theoretical observational bias during telephone interviews, any data disclosing whether the subject was a case or a control were removed from the questionnaires before they were completed over the phone. The final coding of the answers was also done blinded in this respect.

In the analyses univariate as well as multivariate methods were used. To our knowledge this is the first study using multivariate analysis to dissolve different specific risk factors for myeloma among farmers, although some studies have used this method to evaluate farming $v$ other risk factors outside farming $^{29}$ or $v$ pesticides specifically. ${ }^{23}$

The study confirmed the earlier finding of farmers being at an increased risk of developing multiple myeloma. Contact with different domestic animals, and exposure to some pesticides (phenoxyacetic herbicides and DDT), were associated with multiple myeloma, thus giving support to some theories regarding the specific risk factors at hand in farming.

Oncogenic zoonotic viruses have been suggested as possible aetiological agents in haematopoetic and lymphatic malignancies in human subjects, as RNA viruses have been connected with such tumours in several mammalian species. ${ }^{51}{ }^{52} \mathrm{It}$ is also interesting to consider a viral disease in mink, Aleutian mink disease, characterised by systemic proliferation of plasma cells associated with marked hyper- $\gamma$ globulinaemia, with some of the affected minks also developing a myeloma-like $\gamma$-globulin spike. This disease has been found in all of the mink raising areas of Scandinavia and North America. Furthermore, a case of Aleutian mink disease in man has been described, ${ }^{53}$ as well as a case of multiple myeloma in a mink handler who, during many years, had been bitten repeatedly on the hands and arms by mink in a farm where the presence of the viral disease was well documented. ${ }^{54}$ In the present study, one case and one control were working with mink raising, and another case worked on a fox farm.

In our study the univariate analysis supported cattle, horses, hogs, sheep, and goats as risk factors for myeloma. This was further supported by doseresponse calculations. The multivariate analysis, however, eliminated hogs and sheep, and decreased the RR somewhat for horses, goats, and cattle. For cattle these results are in accordance with the findings in a study from New Zealand, ${ }^{19}$ whereas horses and goats have not been reported as risk factors for myeloma in any earlier study. The mechanism responsible for this connection between certain domestic animals and multiple myeloma may well be some unknown viral transmission. Interestingly, a virus has been found to be an important aetiological agent in a bovine type of lymphosarcoma prevalent in cattle. ${ }^{556}$ 
On the other hand, this investigation gave no support for any association between poultry and myeloma, an association that has been suggested in some univariate correlation studies from the United States. ${ }^{16} 183057$

The increased $R R$ for exposure to pesticides supported results of an American case-control study in which no particular class of pesticides could be found responsible, however. ${ }^{31}$ In our present study both phenoxyacetic herbicides and DDT gave statistically significant increased RRs for multiple myeloma in the univariate analysis, and although the risks decreased somewhat, and were non-significant in the multivariate analysis, they both remained increased. No earlier studies exist indicating these pesticides as risk factors for multiple myeloma. Some studies have, however, disclosed phenoxyacetic herbicides as risk factors for non-Hodgkin's lymphoma. ${ }^{589}$ Myeloma and lymphoma are related lymphoproliferative diseases with occurrence of both diseases in some families ${ }^{4}$ and a possible common viral aetiology as already discussed. Thus it was an a priori hypothesis in this study that exposure to phenoxyacetic herbicides might be a risk factor for multiple myeloma. Consequently, it is less probable that the risk increase found was due to chance alone. Some of the phenoxy herbicides are contaminated with dioxins and furans, which can be highly toxic substances. The dioxin isomer $2,3,7,8-\mathrm{TCDD}$ is a recognised carcinogen in animals ${ }^{60-62}$ and other isomers also seem to have this property. ${ }^{6364} \mathrm{~A}$ recent epidemiological study indicated that dioxins in phenoxyacetic herbicides and chlorophenols might be a risk factor for soft tissue sarcoma in human subjects. ${ }^{65} \mathrm{~A}$ carcinogenic effect by the phenoxyacetic herbicides themselves cannot be excluded, however.

DDT is a potent insecticide, the use of which was cancelled in the United States in 1972, and in Sweden in 1975, because of its harmful ecological effects, particularly on predatory birds and on marine life. It is a stable substance and may accumulate in human tissue where it is a potent inducer of the microsomal enzyme system of the liver. Carcinogenicity of DDT is also established in mice, causing liver and lung neoplasms as well as malignant lymphoma. ${ }^{66}$ Liver tumours have also been found in DDT treated rats. ${ }^{67} 68$ Some epidemiological studies indicate a possible association between exposure to DDT and malignant lymphoma or chronic lymphatic leukaemia in human subjects. ${ }^{58690} \mathrm{~T}^{\mathrm{T}}{ }_{\text {.1 }}$. may lend support to the indication of DDT as a risk factor for myeloma in our study, a finding not described earlier. Other pesticides such as creosote and arsenic have been connected to myeloma in some studies, but these findings were not verified in our present study.

Occupational exposure to asbestos as well as organic solvents, which in some, but not all, earlier studies have been identified as possible risk factors for multiple myeloma, were both negatively associated with myeloma in this study, thereby opposing any idea of association between these substances and multiple myeloma.

In the univariate, but not in the multivariate analysis, work with power saws gave a statistically significant increased risk for myeloma. A non-significant risk was also seen for tractor driving. These risks are reflected by the slightly increased risk for occupational exposure to engine exhausts found by univariate analysis. An association between engine exhausts and multiple myeloma was first suggested in an earlier Swedish study, ${ }^{29}$ in which the possible role of the known mutagenic agents in both diesel and gasoline exhausts was emphasised.

In the same study ${ }^{29}$ woodworkers in contact with fresh wood were found to be at increased risk for myeloma, which prompted us to evaluate the risk for people occupied in forestry, at a sawmill, or at a pulp industry combined. The moderately increased risk found in the univariate analysis was eliminated when logistic regression was performed.

A protective effect of being an electrician, or being exposed to electromagnetic fields in any occupation, was a constant finding with statistical significance even in the multivariate analysis. Display monitor units may generate weak electromagnetic fields, and their influence was studied separately. In this case also, exposure seemed to lower the risk for multiple myeloma, but the exposed subjects were few. On the other hand, the RR was close to unity regarding exposure to electromagnetic fields from power lines near the subjects' homes, with exposure defined as living less than $1000 \mathrm{~m}$ from the power line. The risk was not substantially influenced by the distance between home and power line $(100 \mathrm{~m}$ and $500 \mathrm{~m}$ as criteria). No physical or biological explanation is forthcoming for the decreased risk seen in relation to occupational exposure to electromagnetic fields. Ongoing studies-for example, in Sweden-will hopefully shed more light upon the possible association between electromagnetic fields and different types of malignant tumours.

In conclusion, this case-control study confirmed the association between farming and multiple myeloma. Within this occupation the domestic animals, cattle, goats, and horses, and two types of pesticides, phenoxyacetic acids and DDT, were indicated as risk factors. Occupational exposures to electromagnetic fields, asbestos, and organic solvents should be further considered with regard to whether or not some mechanism could explain the decreased risk for myeloma for those exposures, which appeared in this study.

This study was supported by grants from the Swedish Cancer Fund (project 2683-B90-02X). 
We thank Anna-Lena Zakari for performing excellent telephone interviews. We are also grateful to Monica Sandström and Ingemar Majholm for professional assistance in the data collection, and to Professor Olav Axelson for valuable viewpoints and constructive criticism.

Requests for reprints to: Mikael Eriksson, MD, Department of Oncology, University Hospital, S-901 85 Umeå, Sweden.

1 Maldonado JE, Kyle RA. Familial myeloma. Report of eight families and a study of serum proteins in their relatives. $A m \boldsymbol{J}$ Med 1974:57:875-84.

2 Shoenfeld Y, Shaklai M, Berliner S, Gallant LA, Pinkhas J. Familial multiple myeloma: A review of 37 families. Postgrad Med J 1982;58:12-6.

3 Bourguet CC, Grufferman S, Delzell E, DeLong ER, Cohen HJ. Multiple myeloma and family history of cancer. A case-control study. Cancer 1985;56:2133-9.

4 Eriksson M, Bergström I. Familial malignant blood disease in the county of Jämtland, Sweden. Eur J Haematol 1987;38:241-5.

5 Schull WJ. Atomic bomb survivors: Patterns of cancer risk. In: Boice Jr JD, Fraumeni Jr JF, eds. Radiation carcinogenesis: epidemiology and biological significance. New York: Raven Press, 1984:21-36.

6 Finch SC. Leukaemia and lymphoma in atomic bomb survivors. In: Boice Jr JD, Fraumeni Jr JF, eds. Radiation carcinogenesis: epidemiology and biological significance. New York: Raven Press, 1984:37-44.

7 Preston DL, Kato H, Kopecky KJ, Fujita S. Studies of the mortality of A-bomb survivors. 8. Cancer mortality, 19501982. Radiat Res 1987;111:151-78.

8 Gilbert ES, Marks S. An analysis of the mortality of workers in a nuclear facility. Radiat Res 1979;79:122-48.

9 Gilbert ES, Marks S. An updated analysis of mortality of workers in a nuclear facility. Radiat Res 1980;83:740-1.

10 Tolley HD, Marks S, Buchanan JA, Gilbert ES. A further update of the analysis of mortality of workers in a nuclear facility. Radiat Res 1983;95:211-3.

11 Gilbert ES, Petersen GR, Buchanan JA. Mortality of workers at the Hanford Site: 1945-1981. Health Phys 1989;56:11-25.

12 Cuzick J. Radiation-induced myelomatosis. N Engl J Med 1981; 304:204-10.

13 Milham Jr S. Leukaemia and multiple myeloma in farmers. $\mathrm{Am} \mathrm{J}$ Epidemiol 1971;94:307-10.

14 Agu VU, Christensen BL, Buffler PA. Geographic patterns of multiple myeloma: Racial and industrial correlates, State of Texas, 1969-71. J Natl Cancer Inst 1980;65:735-8.

15 Burmeister LF. Cancer mortality in Iowa farmers, 1971-78. $J$ Natl Cancer Inst 1981;66:461-4.

16 Burmeister LF, Everett GD, van Lier SF, Isacson P. Selected cancer mortality and farm practices in Iowa. Am J Epidemiol 1983;118:72-7

17 Gallagher RP, Spinelli JJ, Elwood JM, Skippen DH. Allergies and agricultural exposure as risk factors for multiple myeloma. Br J Cancer 1983;48:853-7.

18 Cantor KP, Blair A. Farming and mortality from multiple myeloma: A case-control study with the use of death certificates. J Natl Cancer Inst 1984;72:251-5.

19 Pearce NE, Smith AH, Howard JK, Sheppard RA, Giles HJ, Teague CA. Case-control study of multiple myeloma and farming. Br J Cancer 1986;54:493-500.

20 Nandakumar A, Armstrong BK, de Klerk NH. Multiple myeloma in Western Australia: A case-control study in relation to occupation, father's occupation, socioeconomic status and country of birth. Int $J$ Cancer 1986;37:223-6.

21 Cuzick J, De Stavola B. Multiple myeloma-A case-control study. Br J Cancer 1988;57:516-20.

22 La Vecchia C, Negri E, D'Avanzo B, Franceschi S. Occupation and lymphoid neoplasms. Br J Cancer 1989;60:385-8.

23 Boffetta P, Stellman SD, Garfinkel L. A case-control study of multiple myeloma nested in the American cancer society prospective study. Int J Cancer 1989;43:554-9.

24 Alavanja MCR, Blair A, Merkle S, Teske J, Eaton B. Mortality among agricultural extension agents. Am J Ind Med 1988;14: $167-76$

25 Steineck G, Wiklund K. Multiple myeloma in Swedish agricultural workers. Int J Epidemiol 1986;15:321-5.
26 McLaughlin JK, Linet MS, Stone BJ, et al. Multiple myeloma and occupation in Sweden. Arch Environ Health 1988;43: 7-10.

27 Linet MS, Harlow SD, McLaughlin JK. A case-control study of multiple myeloma in whites: Chronic antigenic stimulation, occupation, and drug use. Cancer Res 1987;47:2978-81.

28 Brownson RC, Reif JS. A cancer registry-based study of occupational risk for lymphoma, multiple myeloma and leukaemia. Int J Epidemiol 1988;17:27-32.

29 Flodin U, Fredriksson M, Persson B. Multiple myeloma and engine exhausts, fresh wood, and creosote: A case-referent study. Am J Ind Med 1987;12:519-29.

30 Saftlas AF, Blair A, Cantor KP, Hanrahan L, Andersson HA. Cancer and other causes of death among $W$ isconsin farmers. Am J Ind Med 1987;11:119-29.

31 Morris PD, Koepsell TD, Daling JR, et al. Toxic substance exposure and multiple myeloma: A case-control study. J Natl Cancer Inst 1986;76:987-94.

32 Schwartz DA, Vaughan TL, Heyer NJ, et al. B cell neoplasms and occupational asbestos exposure. Am J Ind Med 1988;14: 661-71.

33 Rinsky RA, Smith AB, Hornung R, et al. Benzene and leukaemia. An epidemiologic risk assessment. $N$ Engl J Med 1987;316:1044-50.

34 Lundberg I. Mortality and cancer incidence among Swedish paint industry workers with long-term exposure to organic solvents. Scand J Work Environ Health 1986;12:108-13.

35 Thomas TL, Decoufle P, Moure-Eraso R. Mortality among workers employed in petroleum refining and petrochemical plants. J Occup Med 1980;22:97-103.

36 Ott MG, Holder BB, Gordon HL. Respiratory cancer and occupational exposure to arsenicals. Arch Environ Health 1974;29:250-5.

37 Axelson O, Dahigren E, Jansson C-D, Rehnlund SO. Arsenic exposure and mortality: a case-referent study from a Swedish copper smelter. Br J Ind Med 1978;35:8-15.

38 Greene MH, Hoover RN, Eck RL, Fraumeni JF. Cancer mortality among printing plant workers. Environ Res 1979; 20:66-73.

39 Guidotti S, Wright WE, Peters JM. Multiple myeloma in cosmetologists. Am J Ind Med 1982;3:169-71

40 Spinelli JJ, Gallagher RP, Band PR, Threlfall WJ. Multiple myeloma, leukemia, and cancer of the ovary in cosmetologists and hairdressers. Am J Ind Med 1984;6:97-102.

41 Gallagher RP, Threlfall WJ. Cancer mortality in metal workers Can Med Assoc J 1983;129:1191-4.

42 von Dörken H, Vollmer I. Die epidemiologie des multiplen Myeloms. Arch Geschwulstforsch 1968;31/1:18-38.

43 Walrath J, Decoufle P, Thomas T. Mortality among workers in a shoe manufacturing company. Am J Ind Med 1987;12:615-23.

44 Brinton LA, Stone BJ, Blot WJ, Fraumeni JF. Nasal cancer in U.S. furniture industry counties. Lancet 1976;ii:628.

45 Tollerud DJ, Brinton LA, Stone BJ, Tobacman JK, Blattner WA. Mortality from multiple myeloma among North Carolina furniture workers. J Natl Cancer Inst 1985;74:799-801.

46 Milham Jr S. Increased mortality in amateur radio operators due to lymphatic and hematopoietic malignancies. Am J Epidemio 1988;127,1:50-4.

47 Committee of the chronic leukemia-myeloma task force, NCI Proposed guidelines for protocol studies. II. Plasma cell myeloma. Cancer Chemother Rep 1968;1:17-39.

48 Swedjemark GA. In-door measurements on natural radioactivity in Sweden. Stockholm: National Board of Radiation Protection, (SSI). 1979. Report 1979-026. (In Swedish.)

49 Miettinen OS. Estimation of relative risk from individually matched series. Biometrics 1970;26:75-86.

50 Fredriksson M, Hardell L, Bengtsson NO, Axelson O. Confounding in occupational studies. In: Hogstedt C, Reuterwal C, eds. Progress in occupational epidemiology. Amsterdam: Elsevier Science Publishers, 1988:63-6.

51 Kaplan HS. From experimental animal models to human lymphoid tissue neoplasia: search for viral etiology. In: Mathe G, Seligmann M, Tubiana M, eds. Recent results in cancer research. Lymphoid neoplasia. I: Classification, categorisation, natural history. Heidelberg: Springer-Verlag, 1978; 325-36.

52 Armenian HK, Hamaden RR. Epidemiology of non-Hodgkin's lymphomas. In: Lilienfeld AM, ed. Reviews in cancer epidemiology. Vol 2. New York: Elsevier, 1983.

53 Chapman I, Jimenez FA. Aleutian-mink disease in man. $N$ Engl JMed 1963;269:1171-4.

54 Henry LW. Multiple myeloma in a mink handler following exposure to aleutian disease. Cancer 1979;44:273-5.

55 Ressang AA, Mastenbrook N, Quak J, et al. Studies on bovine 
leukemia. I. Establishment of type $C$ virus producing cell lines. Zentralbl Veterinarmed (B) 1974;21:602-17.

56 Kettmann R, Portetelle M, Mammerickx M, et al. Bovine leukemia virus: an exogenous RNA oncogenic virus. Proc Natl Acad Sci USA 1976;73:1014-8.

57 Priester WA, Mason TJ. Human cancer mortality in relation to poultry population, by county, in 10 southeastern states. $J$ Natl Cancer Inst 1974;53:45-9.

58 Hardell L, Eriksson M, Lenner P, Lundgren E. Malignant lymphoma and exposure to chemicals, especially organic solvents, chlorophenols and phenoxy acids; A case-control study. Br J Cancer 1981;43:169-76.

59 Hoar SK, Blair A, Holmes FF, et al. Agricultural herbicide use and risk of lymphoma and soft-tissue sarcoma. JAMA 1986; 256:1141-7.

60 Kociba RJ, Keyes DG, Beyer JE, et al. Results of a two-year chronic toxicity and oncogenicity study of 2,3,7,8-tetrachlorodibenzo-p-dioxin in rats. Toxicol Appl Pharmacol 1978;46: 279-303.

61 Pitot HC, Goldsworthy T, Campbell HA, et al. Quantitative evaluation of the promotion by $2,3,7,8$,-tetrachlorodibenzo-pdioxin of hepatocarcinogenesis from diethylnitrosamine. Cancer Res 1980;40:3616-20.

62 van Miller JP, Lalich JJ, Allen JR. Increased incidence of neoplasm in rats exposed to low levels of 2,3,7,8-tetrachlorodibenzo-p-dioxin. Chemosphere 1977;6:537-44.

63 National toxicology program, National Cancer Institute. NIH bioassay of a mixture of $1,2,3,6,7,8$ and $1,2,3,7,8,9$-hexachloro dibenzo-p-dioxins for carcinogenicity (gavage study). (Natl Toxicol Program tech rep ser No 198; DHHS publ No (NIH)80-198.) Research Triangle Park, NC: Natl Toxicol Program, 1980.

64 National toxicology program, National Cancer Institute. Toxicology and carcinogenesis studies of two penta-chlorophenol technical-grade mixtures $B 6 C 3 F_{1}$ mice. (Natl Toxicol Program tech rep ser No 349; DHHS publ No (NIH)89-2804.) Research Triangle Park, NC: Natl Toxicol Program, 1989.

65 Eriksson M, Hardell L, Adami H-O. Exposure to dioxins as a risk factor for soft tissue sarcoma: A population-based casecontrol study. J Natl Cancer Inst 1990;82:486-90.

66 Kashyap SK, Nigam SK, Karnick AB, et al. Carcinogenicity of DDT (dichlorodiphenyltricloroethane) in pure inbred Swiss mice. Int J Cancer 1977;19:725-29.

67 Rossi L, Ravera M, Repetti G, et al. Long-term administration of DDT or phenobarbital Na in Wistar rats. Int J Cancer 1977; 19:179-85.

68 Cabral JRP, Hall RK, Rossi L, et al. Effects of long-term intakes of DDT on rats. Tumori $1982 ; 68: 11-7$.

69 Persson B, Dahlander AM, Fredriksson M, Noorlind Brage H, Ohlson C-G, Axelson $O$. Malignant lymphomas and occupational exposures. Br J Ind Med 1989;46:516-20.

70 Flodin U, Fredriksson M, Persson B, Axelson O. Chronic lymphatic leukaemia and engine exhausts, fresh wood, and DDT: a case-referent study. Br J Ind Med 1988;45:33-8.

Accepted 3 June 1991

\section{Vancouver style}

All manuscripts submitted to the $B r J$ Ind Med should conform to the uniform requirements for manuscripts submitted to biomedical journals (known as the Vancouver style).

The $\mathrm{Br} J$ Ind Med, together with many other international biomedical journals, has agreed to accept articles prepared in accordance with the Vancouver style. The style (described in full in $\mathrm{Br}$ Med J, 24 February 1979, p 532) is intended to standardise requirements for authors.

References should be numbered consecutively in the order in which they are first mentioned in the text by Arabic numerals above the line on each occasion the reference is cited (Manson ${ }^{1}$ confirmed other reports $\left.{ }^{2-5} \ldots\right)$. In future references to papers submitted to the $\mathrm{Br} J$ Ind Med should include: the names of all authors if there are six or less or, if there are more, the first three followed by $e t a l$; the title of journal articles or book chapters; the titles of journals abbreviated according to the style of Index Medicus; and the first and final page numbers of the article or chapter.

Examples of common forms of references are:

1 International Steering Committee of Medical Editors. Uniform requirements for manuscripts submitted to biomedical journals. Br Med J 1979;1:532-5.

2 Soter NA, Wasserman SI, Austen KF. Cold urticaria: release into the circulation of histamine and eosino-phil chemotactic factor of anaphylaxis during cold challenge. N Engl J Med 1976;294:687-90.

3 Weinstein L, Swartz MN. Pathogenic properties of invading micro-organisms. In: Sodeman WA Jr, Sodeman WA, eds. Pathologic physiology: mechanisms of disease. Philadelphia: W B Saunders, 1974:457-72. 